Article

\title{
Interseismic Deformation of the Altyn Tagh Fault Determined by Interferometric Synthetic Aperture Radar (InSAR) Measurements
}

\author{
Sen Zhu ${ }^{1}$, Caijun $\mathrm{Xu}{ }^{1,2,3, *}$, Yangmao Wen ${ }^{1,2,3}$ and Yang Liu 1,2,3 \\ 1 School of Geodesy and Geomatics, Wuhan University, Wuhan 430079, China; zs0255@163.com (S.Z.); \\ ymwen@sgg.whu.edu.cn (Y.W.); yang.liu@sgg.whu.edu.cn (Y.L.) \\ 2 Key Laboratory of Geospace Environment and Geodesy, Ministry of Education, Wuhan 430079, China \\ 3 Collaborative Innovation Center of Geospatial Technology, Wuhan 430079, China \\ * Correspondence: cjxu@sgg.whu.edu.cn; Tel.: +86-27-6877-8805; Fax: +86-27-6877-8371 \\ Academic Editors: Zhenhong Li, Roberto Tomas, Zhong Lu and Prasad S. Thenkabail \\ Received: 27 November 2015; Accepted: 4 March 2016; Published: 11 March 2016
}

\begin{abstract}
The Altyn Tagh Fault (ATF) is one of the major left-lateral strike-slip faults in the northeastern area of the Tibetan Plateau. In this study, the interseismic deformation across the ATF at $85^{\circ} \mathrm{E}$ was measured using 216 interferograms from 33 ENVISAT advanced synthetic aperture radar images on a descending track acquired from 2003 to 2010, and 66 interferograms from 15 advanced synthetic aperture radar images on an ascending track acquired from 2005 to 2010. To retrieve the pattern of interseismic strain accumulation, a global atmospheric model (ERA-Interim) provided by the European Center for Medium Range Weather Forecast and a global network orbital correction approach were applied to remove atmospheric effects and the long-wavelength orbital errors in the interferograms. Then, the interferometric synthetic aperture radar (InSAR) time series with atmospheric estimation model was used to obtain a deformation rate map for the ATF. Based on the InSAR velocity map, the regional strain rates field was calculated for the first time using the multi-scale wavelet method. The strain accumulation is strongly focused on the ATF with the maximum strain rate of $12.4 \times 10^{-8}$ /year. We also show that high-resolution 2-D strain rates field can be calculated from InSAR alone, even without GPS data. Using a simple half-space elastic screw dislocation model, the slip-rate and locking depth were estimated with both ascending and descending surface velocity measurements. The joint inversion results are consistent with a left-lateral slip rate of $8.0 \pm 0.7 \mathrm{~mm} /$ year on the ATF and a locking depth of $14.5 \pm 3 \mathrm{~km}$, which is in agreement with previous results from GPS surveys and ERS InSAR results. Our results support the dynamic models of Asian deformation requiring low fault slip rate.
\end{abstract}

Keywords: InSAR; AltynTagh Fault; interseismic deformation; geodetic inversion; slip rate

\section{Introduction}

The ongoing active continental collision between the Indian and Eurasian plates has created the massive topography of the Tibetan Plateau over the last 50 million years. The tectonic processes underlying this region are still not completely understood and a number of models have been proposed to explain the dynamics of the area [1-4]. The active Altyn Tagh Fault (ATF) is a distinctive feature of Tibetan geography, inscribing a fairly linear trace over $1500 \mathrm{~km}$ across northern Tibet (Figure 1), separating the high plateau in the south from the low Tarim Basin in the north. The Tibetan Plateau south of the ATF has an average elevation of $\sim 4000 \mathrm{~m}$, whereas the northern Tarim Basin has an average elevation of only $\sim 1000 \mathrm{~m}$. The ATF begins in the west at the Pamir Mountains and ends in the east near the Qilian Mountains. It is generally accepted that the ATF is divided into three segments, the west, middle, and east, between $84^{\circ} \mathrm{E}$ and $94^{\circ} \mathrm{E}$ [5]. It is a major tectonic element in 
the Cenozoic Indo-Asian collision zone [6] that defines the northern margin of the Tibetan Plateau. It plays a key role in identifying the Tibet deformation patterns and its slip rates have constituted an important constraint for deriving the velocity field of East Asia [7]. Some studies argued that the ATF might accommodate as much as one-third of the overall convergence between India and Siberia [7]. Zhang et al. [8] derived the velocity field of the present day tectonic deformation in the Tibetan Plateau using 553 GPS observations. The velocity distribution suggested that the relative movement between the Indian and Eurasian plates was adjusted and absorbed by crustal shortening and internal strike-slip shearing in the Tibetan Plateau. In particular, the Himalaya Mountains absorbed 44\%-53\% of the total shortening, while the Qaidam Basin, Qilian Mountains, and Altyn Mountains in the north absorbed $15 \%-17 \%$, and the interior of the plateau absorbed the remaining $32 \%-41 \%$. It has been regarded as either a lithospheric-scale strike-slip fault promoting the eastward extrusion of Tibet [9] or a crustal-scale transfer fault linking thrust belts [10].

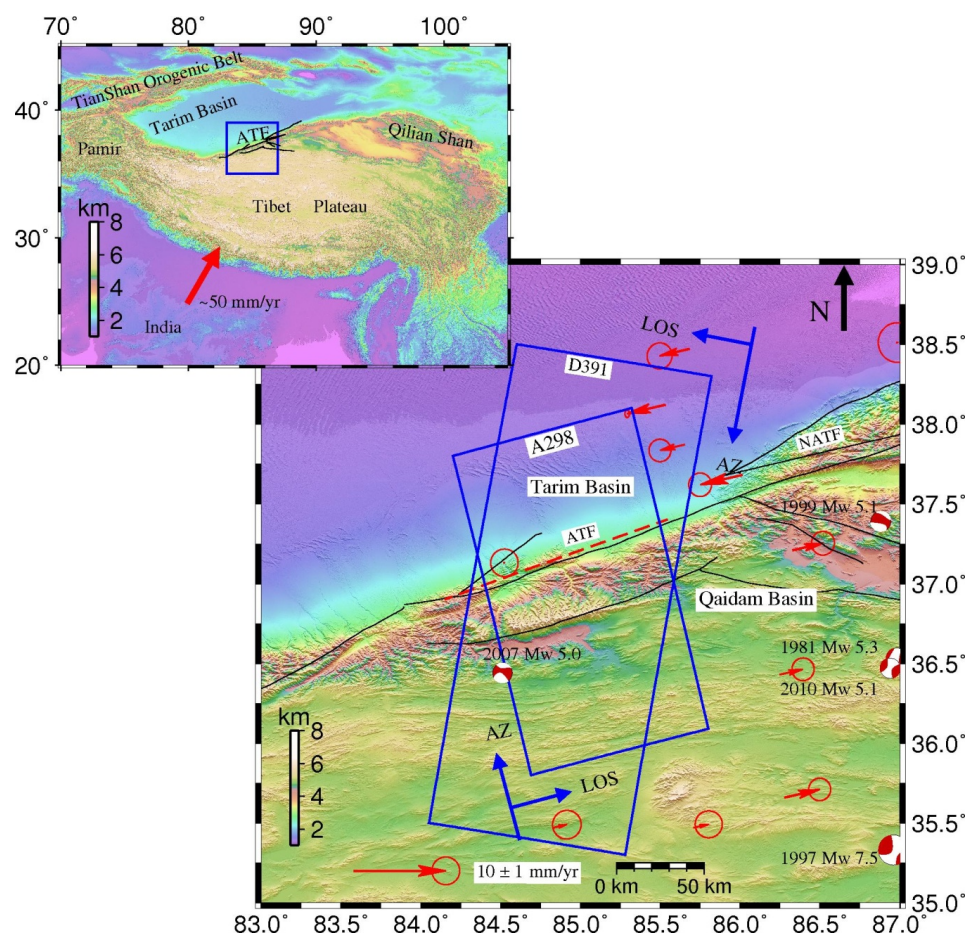

Figure 1. Location and velocity map of the Altyn Tagh Fault (ATF). The top left figure shows the whole tectonic background of the ATF, the low right figure is the zoom-in of the blue rectangular in it and shows the velocity map. In the low right part, the black solid line indicates the ATF. The blue rectangle is the InSAR frame of D391 and A298. The red dashed line is the estimated fault location, and the blue arrows represent the azimuth and LOS direction. The focal mechanism symbols represent the events after 1976 from the Harvard CMT catalogue. The black arrow shows the north direction. The red arrows with ellipses show the GPS velocity projected to the rough fault line. The GPS velocity is from Ge et al. [11].

There are two end-member models for the continental deformation mechanism in Tibet accommodating the Indian sub-continent collision with Eurasia: block and microplate models and continuum models. To discriminate between these two models, we need to determine the slip rate of the ATF accurately. Late Quaternary slip rates have been reported along most of the ATF at both decadal and millennial time scales. Geodetic measurements at the decadal time scale indicating that the ATF slips at $10 \mathrm{~mm} /$ year [12-15] have been used to support continuum deformation of the Tibetan Plateau [1,2,8,15] or block-like deformation [3,4]. Elliott et al. [16] investigated the same location as this study using ERS data and the stacking method and concluded that the slip rate was $11 \pm 5 \mathrm{~mm} /$ year, 
supporting continuum deformation. In contrast, He et al. [17] tried to determine the slip rate using a GPS profile, and their conclusion was $9.0 \pm 4.0 \mathrm{~mm} /$ year, consistent with block-like deformation. At a millennial time scale, the geological slip rate is given as $27 \pm 7 \mathrm{~mm}$ /year from detailed measurements of riser offsets of different geomorphic terraces using radiocarbon and cosmic ray exposure dating of the offset terraces [18].

In the past two decades, InSAR [19] has become a widely used deformation mapping tool in studying geophysical process. Since the first coseismic interferogram was published [20] in the 1992 Mw 7.4 Landers earthquake, InSAR has made significant contributions to earthquake cycle research (e.g., [20-24]). Wright et al. [21] first retrieved the interseismic slip rate of strike-slip fault using stacking method. Walters et al. [22] improved Wright and coworkers' results using SAR data from two look directions, reducing the range of uncertainties of slip rate and locking depth by $60 \%$. At present, InSAR is regarded as a significant tool for tectonic geomorphology and seismic hazard assessment [25]. In this paper, InSAR observations are the major source of data for the determination of slip rate and locking depth of the ATF.

Although geodetic measurements are consistent with others that estimated $10 \mathrm{~mm} /$ year, they differ significantly from rates determined by geological methods (27 $\pm 7 \mathrm{~mm} /$ year; [18]) and have significant uncertainties. In this study, we attempted to determine a highly accurate slip rate of the left-strike ATF using the interferometric synthetic aperture radar (InSAR) time series with atmospheric estimation model (TS + AEM) package with the same descending track (D391) as Elliott et al. [16], as well as an ascending track (A298) of ENVISAT data after the atmospheric and orbital errors were removed. In order to determine whether there is significant strain accumulation away from the major faults, the strain rate field was calculated based on horizontal velocity field using the multi-scale waveform method proposed by Tape et al. [26]. The fault slip rates are inverted based on a half-space elastic screw dislocation model. Finally, we interpreted the geodetic velocity field and investigated the essence of crustal deformation in this region.

\section{Interseismic Rate Map from InSAR Time Series}

InSAR has the potential to measure interseismic strain accumulation at a dense spatial scale. It is widely used to estimate the slip rates of major faults $[16,21,22,27,28]$ since Massonnet et al. successfully extracted the coseismic deformation of the 1992 Landers earthquake [20]. Wright et al. [21] werethe first to use InSAR for studying the interseismic deformation. InSAR has been proven to be a important tool in researching the seismic cycle deformation after many successful applications in coseismic [20], postseismic [29] and interseismic [16,21,22,27,28] deformation. Walters et al. [22] improved Wright and coworkers' results [21] by using SAR data from two different look directions, in their paper, they stated that the uncertainties in slip rate and locking depth are reduced up to $60 \%$ which is a huge improvement. In our study, we used two directions SAR data in order to obtain the deformation of ATF following Waltersand coworkers' method [22]. Crustal deformation signals measured over short time scales are dominated by orbital and atmospheric errors. Interseismic deformation can be extracted from several interferograms when the atmospheric and orbital errors are removed.

\subsection{InSAR Data and Processing}

Synthetic aperture radar images from the advanced SAR (ASAR) instrument on board the ENVISAT satellite were used in this study to investigate interseismic deformation across the ATF at $85^{\circ} \mathrm{E}$. The data set was acquired between June 2003 and June 2010, and includes 33 descending images and 15 ascending images. The raw data were processed with repeat orbit interferometry package (ROI_PAC) Version 3.1 beta [30]. Precise DORIS orbital data for ENVISAT satellite provided by ESA has been used for interferometric processing. All of the interferograms were produced using the NSBAS package [31,32]. Image pairs were selected by spatial and temporal baselines: (i) $B_{t}<1$ year and $\mathrm{B}_{\mathrm{s}}<500 \mathrm{~m}$; (ii) $\mathrm{B}_{\mathrm{t}}<3$ year and $\mathrm{B}_{\mathrm{s}}<300 \mathrm{~m}$; and (iii) $\mathrm{B}_{\mathrm{t}}<5$ year and $\mathrm{B}_{\mathrm{s}}<100 \mathrm{~m}$ (Figure 2). In ascending track 298, the 10 October 2005data extends the time baseline from 2 to 5 years, which is significant for 
the time series deformation analysis. Unlike ROI_PAC, the NSBAS takes into account the DEM when co-registering images [33], which improved the interferometric processing and increased the coherence of interferograms.
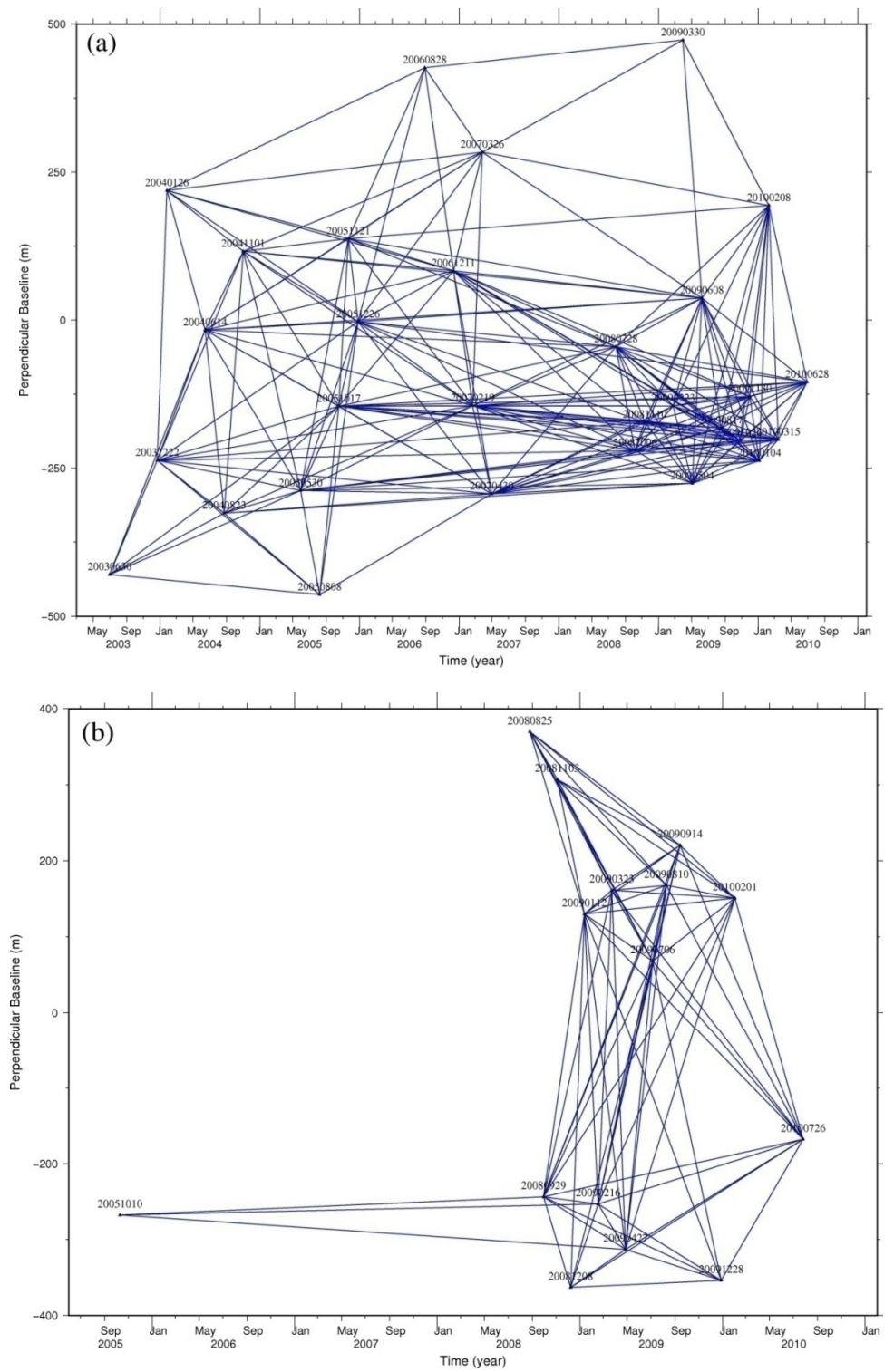

Figure 2. Temporal and spatial baseline of InSAR interferograms: (a) D391 and (b) A298.

During SAR data processing, we multilooked the SAR images 4 and 20 times in the azimuth and range directions, respectively, during processing to improve the signal-to-noise ratio. The phase component of the topography was removed using the three-arc second shuttle radar topography mission (SRTM) DEM [34] with the ESA DORIS precision orbits. A power spectrum filter [35] was applied to further reduce the phase noise to improve the interferogram coherence. Most interferograms were unwrapped using the branch-cut method [36], but some of them needed manual unwrapping (bridge) across the fault due to the loss of coherence. The unwrapping errors were detected and removed by a phase-closure technique $[37,38]$. After phase closure check, we correct the atmospheric errors and orbital ramps (Figure 3) respectively. The whole process flow is summarized in Figure 4. The coherence of north areas of the ATF was commonly higher than that of the southern part because of snow cover on the southern mountains (Figure 5). Areas near the ATF have poor coherence even compared with the southern part as a result of the topography. 


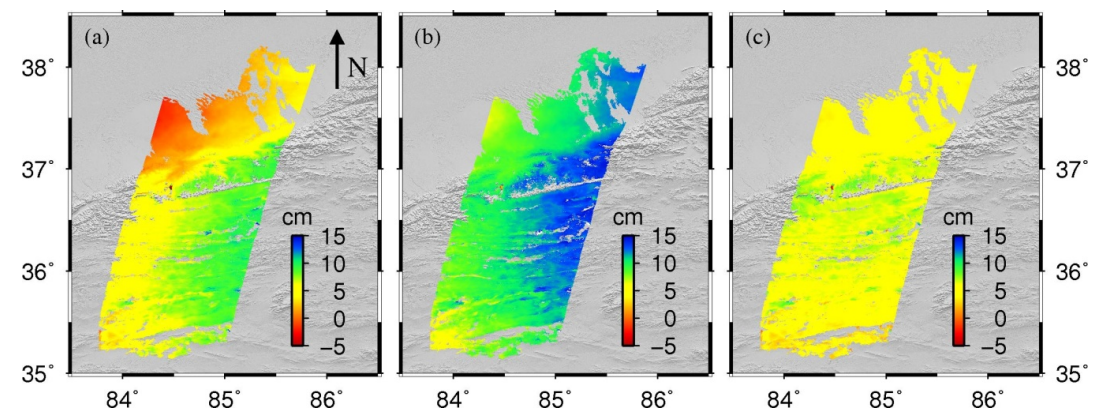

Figure 3. Example interferogram (17 October 2005-19 February 2007) showing the effects of APS and orbit correction. (a) observation interferogram; (b) APS corrected interferogram (using TRAIN software); (c) orbit corrected interferogram (using Biggs's network correction method).

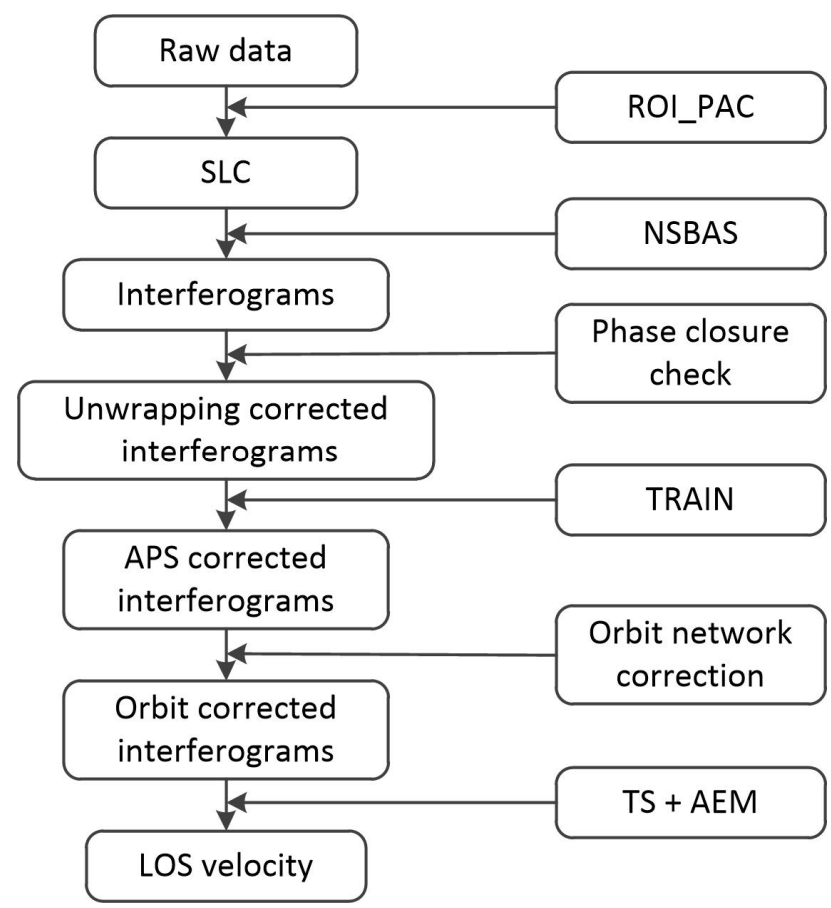

Figure 4. Flow chart of data processing, from raw data to final LOS velocity.
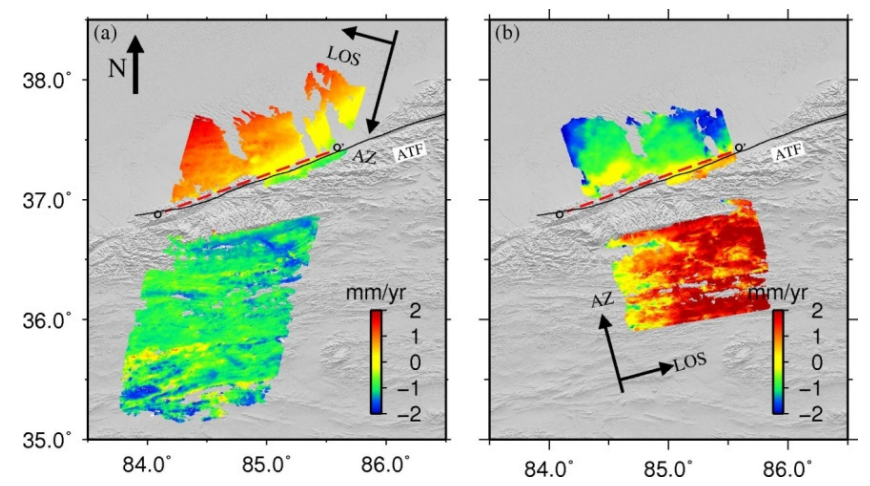

Figure 5. (a) Ground surface mean LOS velocity maps from InSAR time series analysis for D391. The fat black arrow shows the north direction. The dashed line indicates the fault location used for the 2-D modeling. The $\mathrm{OO}^{\prime}$ line stands for the fault location. (b) Ground surface mean LOS velocity maps from InSAR time series analysis for A298. 


\subsection{Atmospheric Correction}

The greatest factor limiting InSAR measurement accuracy is atmospheric delay, particularly from tropospheric water vapor [39].This is exacerbated for the ATF due to its relief of $\sim 4 \mathrm{~km} \mathrm{[16].} \mathrm{Crustal}$ deformation signals measured over short time scales are dominated by orbital and atmospheric errors. The atmospheric phase delay, mainly derived from the temporal variation of stratified troposphere, may reach tens of centimeters $[40,41]$.

There are two groups of correction methods to estimate atmospheric phase delay, the empirical and the predictive methods. Assuming that the relationship between the atmospheric delays and elevation is approximately linear, a first order function [16,41,42] could be used to estimate the conversion coefficient. Unfortunately, empirical methods cannot be easily used when the expected deformation signal correlates with topography, which is the case for such major topographic steps like ATF [16]. Predictive methods are based on inputs from external data sets to compute synthetic delay maps and directly correct for tropospheric delays in interferograms. The external data sets include local meteorological data [43], GPS zenith delay measurements [44-47], satellite multi-spectral imagery [48,49], and outputs from local meteorological models constrained by local data collection [50-52]. These external data have proven successful and accurate for atmospheric correction; however, rarely available local data limit the popularity of this method.

Here, we use the method from Bekaert et al. $[33,53,54]$ to estimate the atmospheric phase delay maps using the ERA-I global atmospheric model reanalysis product [55] obtained from the European Center for Medium-Range Weather Forecasts. The ERA-I provides estimates of temperature, water vapor partial pressure, and geopotential height along 37 pressure levels, on a global $0.7^{\circ} \times 0.7^{\circ}$ grid at regular 6-hour intervals from 1989 to present. Both hydrostatic and wet contributions to the phase delay are taken into account in this approach (Figure 3). This method accounts for spatial variability of the tropospheric properties and successfully captures tropospheric signals over large regions. In Figure 3, for example, we removed the elevation-correlated atmospheric path delay from original observations to correct for atmospheric errors; in Figure $3 b$, the clear difference across the fault in Figure $3 \mathrm{a}$ is removed denoting the reduction of the elevation-correlated atmospheric delay. We have calculated the standard deviation $(\sigma)$ reduction of the APS correction and find that $\sigma$ is reduced in $38 \%$ by ECMWF-based correction. The results confirm that the ERA-I model can overcome limitations of empirical models [56].

\subsection{Orbital Correction}

Because of our imperfect knowledge of the state vector of the ENVISAT satellite, even after the effects of baseline separation have been removed, an orbital error remains in the interferogram [57]. A clear linear ramp is shown in atmospheric corrected interferogram (Figure $3 b$ ). It is caused by long wavelength orbital errors and the orbital correction is needed before further processing. A linear approximation is usually sufficiently accurate for short strips (100-200 km along track) and a quadratic approximation is required for longer strips. This approach is sufficient because the deformation signal represents a small portion of interferometric phase, such as volcanology and earthquakes [58]. Hence, it is possible to define a "far-field" area of the interferogram and to re-estimate the baseline parameters [37]. However, there is no true "far-field" in such a large area for studies of interseismic deformation, so the baseline for individual interferograms to deal with the orbital contributions cannot be precisely re-estimated.

For this reason, Biggs et al. [37] presented a global network orbital correction method to deal with the issue of orbital contributions at a later stage of re-estimating the baseline. Here, we use this method to remove orbital errors remaining in the interferograms (Figure 3c). It can be seen from Figure 3c that a phase ramp is removed from the atmospheric corrected interferogram (Figure 3b) after the network orbital correction. The $\sigma$ reduction of this step is $13 \%$ of the interferogram. This correction technique also accounts for other long wavelength signals, such as ionospheric and long wavelength tropospheric contributions as well as errors in orbit [37]. 


\subsection{Rate Map}

A LOS rate map is calculated from the interferograms corrected for both atmospheric and orbital errors using the InSAR TS + AEM package developed at the University of Glasgow based on the SBAS algorithm [59-61] as the flow chart in Figure 4. The RMS between LOS deformation derived from the InSAR TS + AEM package and GPS measurements is smaller than $0.5 \mathrm{~mm} /$ year, which was validated independently by Li et al. (Abstract G13B-07 presented at Fall Meeting. 2010, AGU, San Francisco, CA, USA) and Hammond et al. [62].

We obtained the deformation rate map for the ATF from corrected interferograms using the InSAR TS + AEM approach (Figure5). It indicates that the deformation rate of ATF ranges from $-2 \mathrm{~mm} /$ year to $2 \mathrm{~mm} /$ year in the LOS direction. One clear point is that the LOS velocity changes across the ATF in both tracks. The opposite gradient trends on ascending and descending tracks were consistent with left-lateral motion of the ATF system. There is no clear correlation between the topography and the mean-velocity map, indicating that the topography-related atmospheric errors have been successfully removed and that no significant residual atmospheric effect related to the topography is affecting the results.

To test the effect of the isolated 10 October 2005 acquisition to the final velocity results, we performed the inversion without the 10 October 2005 data. The result is shown in Figure 6: the left one (Figure 6a) is the velocity of data set including 10 October 2005 data, whereas the right one (Figure 6b) is velocity result from data set without 10 October 2005 data. From the velocity map we can know that the 10 October 2005 data actually affects the result in some degree (the range of LOS velocity changes from $-2.00 \sim 1.72 \mathrm{~mm}$ /year of data set including 10 October 2005 data to $-2.20 \sim 1.92 \mathrm{~mm} /$ year without 10 October 2005 data), however the first-order deformation characteristics is consistent with the results obtained from all the dataset.
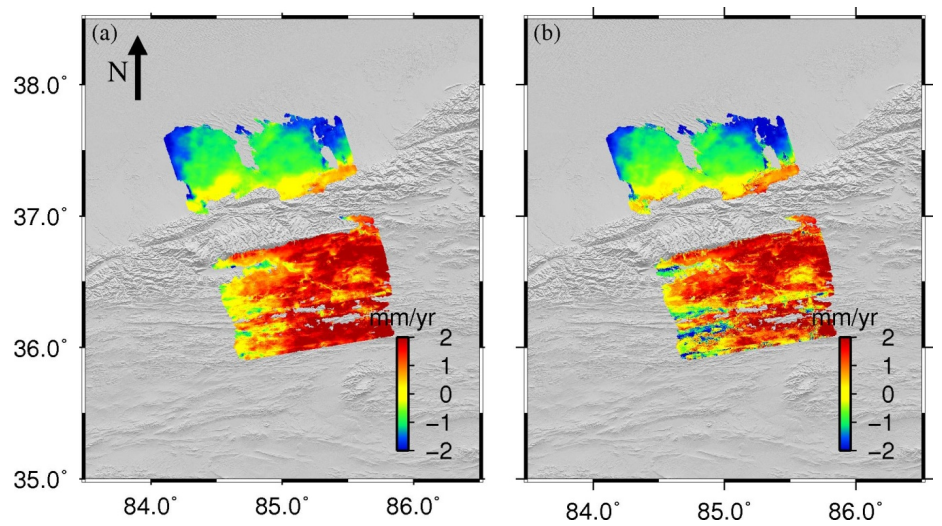

Figure 6. LOS velocity map of Ascending track 298 with (a) and without (b) the 10 October 2005 acquisition.

\subsection{Strain Rate Map}

Strain fields of a region describe the geometric changes caused by deformation and, therefore, its characteristic pattern and amplitude are very important to understanding the present-day tectonic processes and underlying driving forces in this area. The strain rate tensor can be used to study crustal deformation and characterize geodynamic processes, such as strain accumulation, independent of a reference frame. Therefore, it is common to derive the distribution of strain rate fields to capture the tectonic mechanism of a region.

To better constrain the deformation characteristics of the ATF, we calculated the strain rate field in the spherical coordinates from velocity fields using the wavelet-based multi-scale estimation method proposed by Tape et al. [26]. This method can localize a given deformation field in space and scale as well as detect outliers in the observation set. Based on the relative less normal deformation from a GPS 
study [11], we resolved the along-fault velocity using ascending and descending track LOS velocities and used it as the total horizontal velocity. Then we extrapolated the velocity field of this area using the Kriging interpolation method (Figure 7a). Finally, we calculated the three invariant quantities, related dilatation rate, strain rate and rotation rate, which do not depend on the coordinate system.
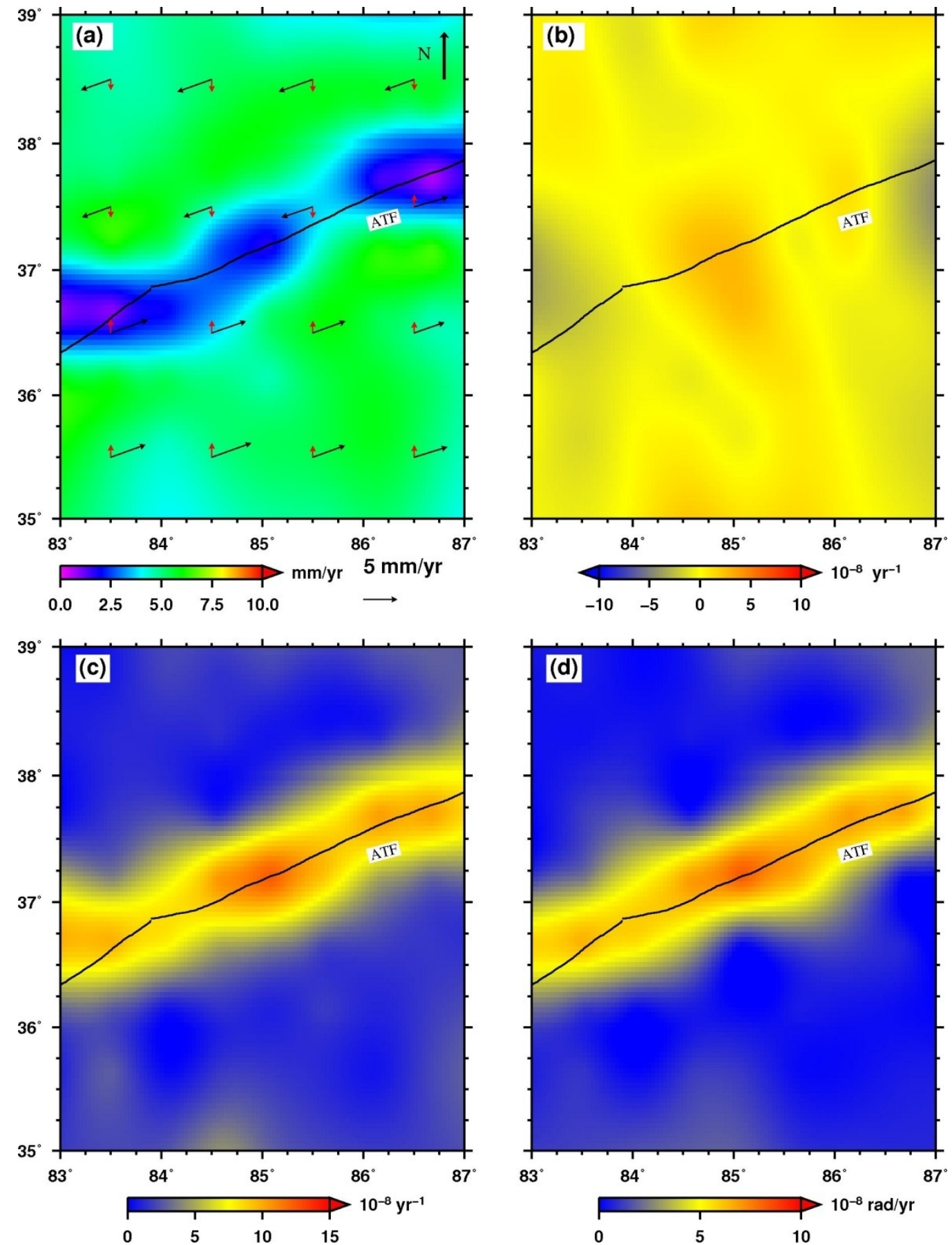

Figure 7. ATF strain map: (a) velocity map, the red arrows show the vertical velocity (directs north means upmotions and south means down motions) and the fat black arrow shows the north direction; (b) dilatation rate; (c) strain rate and (d) rotation rate.

The strain rate field (Figure 7c) exhibits the expected interseismic pattern for a locked fault with a maximum along the fault and symmetric on either side. Strain accumulation is strongly localized on 
the ATF. The northern Tarim Basin and southern high plateau regions are straining at very low rates in comparison to the major strike-slip faults. The maximum strain rate along the fault is approximately $12.4 \times 10^{-8} /$ year. The dilatation rate was nearly zero. The rotation rate has a maximum of approximately $10 \times 10^{-8} /$ year, indicating that rotation can partly account for the deformation in the vicinity of the fault. In comparison to previous studies, our results are consistent in one-order features, although we only calculate the strain rate field across the ATF rather than the whole Tibetan Plateau. The strain rate fields in Figure 7c reproduce the same first-order features as the velocity field, and show that strain is strongly focused on the main left-lateral strike-slip fault. In this study, we have shown that it is possible to create 2-D strain maps using InSAR data from two observations, even in the absence of GPS observations.

\section{Modeling}

As seen from the strain field in Figure 7c, the strain strongly focused on the main left-lateral strike-slip fault, so we can assume that the main contributions to the deformation are from the ATF. To aid in the interpretation of the first-order characteristics of the LOS velocity map, a simple elastic model with single fault geometry was used to invert the slip-rate and locking depth of the ATF. Although one more complex model may be more appropriate for this fault, the lack of data near the fault makes it hard to constrain the deformation using a complex model. Consequently, we assumed a strike-slip fault with $90^{\circ}$ dip angle. We assumed that LOS deformation is a combination of fault parallel deformation and vertical deformation, ignoring normal fault deformation, which is justified by GPS measurements [11]. We modeled the fault as a buried infinite screw dislocation in a homogeneous, isotropic elastic half-space, where aseismic slip occurs at a rate (s) below a locking depth $(d)$ during the interseismic period.

Under this assumption, we converted displacement of two profiles in LOS direction into horizontal displacements parallel to the fault and vertical displacements. We accounted for both horizontal and vertical displacement with two data tracks in our inversion rather than accounting for only horizontal displacement [16] with only one track, in our inversion process the contribution from vertical components is subtracted from the InSAR observations. The relationship between LOS displacements and horizontal and vertical displacement is given by:

$$
d_{l o s}=u_{n} \sin \varphi \sin \theta-u_{e} \cos \varphi \sin \theta+u_{u} \cos \theta
$$

where $\varphi$ is the azimuth angle for the satellite orbit, $\theta$ is the incidence angle, and $u_{(n, e, u)}$ are the north, east, and up components of displacement, respectively. We decomposed the horizontal component of the fault to parallel and normal components and ignored the normal component. As it is one-third smaller with respect to the parallel component and nearly vertical to the LOS direction, its projection to the LOS is negligible. Thus, Equation (1) can be rewritten as:

$$
d_{l o s}=u_{h} \cos \alpha \sin \theta+u_{u} \cos \theta
$$

where $\alpha$ is the angle between the fault line and horizontal projection of LOS. We thus have two unknowns $\left(u_{h}, u_{u}\right)$ and two equations, so it is possible to solve the equations.

The slip rate $(s)$ and locking depth $(d)$ of the fault were determined based on the Savage and Burford [63] analytical solution, which explains the surface velocity $(y)$ parallel to the fault at a given distance $(x)$ from the fault as:

$$
y=\frac{s}{\pi} \tan ^{-1} \frac{x}{d}
$$

We performed an initial parameter search over the $0.5-10.0 \mathrm{~mm} /$ year for slip rate and 5-35 km locking depth with the simulated annealing algorithm [64,65]. Our best-fit model for joint inversion, corresponding to the minimum of RMS misfit, yields a slip rate of $8.0 \mathrm{~mm} /$ year and a locking depth of $14.5 \mathrm{~km}$. The simulation and residuals between observations and simulating results of D391 and A298 are presented in Figures 8 and 9 respectively. The residuals of A298 are not as smooth as D391. This probably results from fewer image dates in the inversion, which again confirms that additional observations can reduce errors. 

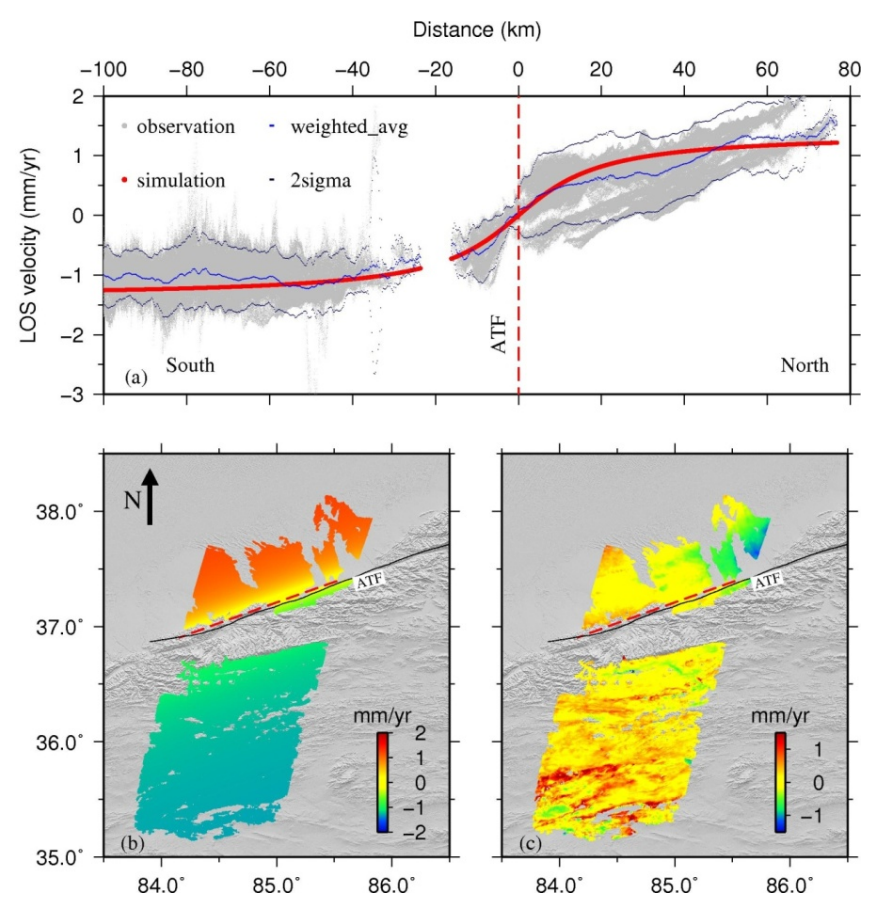

Figure 8. (a) D391 mean LOS velocity profiles (gray dots) and the weighted average profile (dark blue) with $2 \sigma$ deviation (light blue). All of the points shown on the left are projected onto the profile as gray dots. The red line is the best-fit model with a slip rate of $8.0 \mathrm{~mm} /$ year and $14.5 \mathrm{~km}$ locking depth; (b) Model simulation map from the best-fit model values. The fat black arrow shows the north direction; (c) Residuals between model and observation results. The near zero residuals demonstrate the inversion goodness.

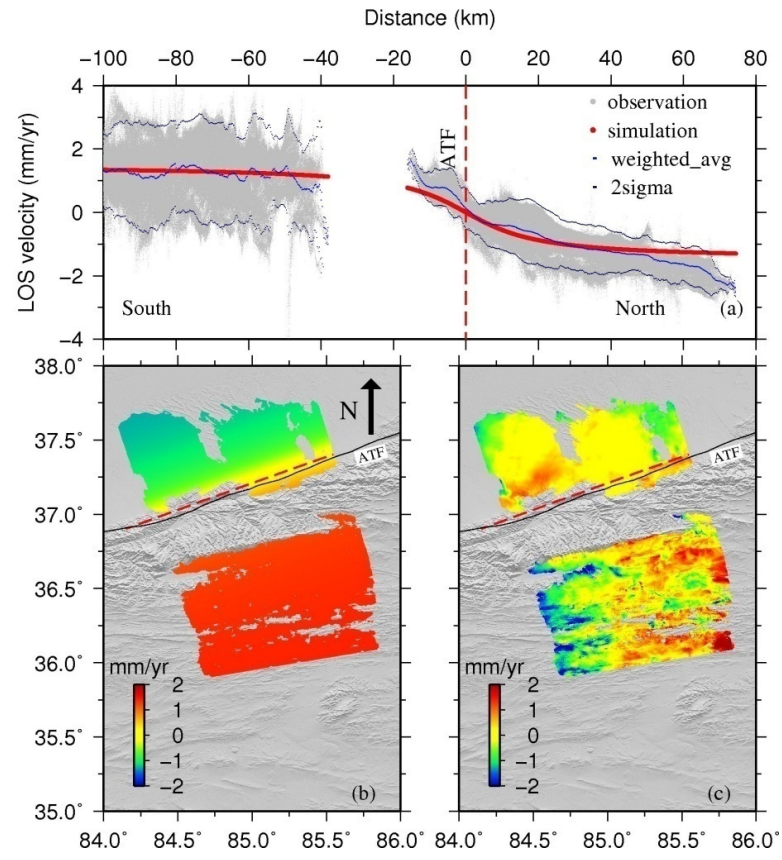

Figure 9. (a) A298 mean LOS velocity profiles (red dots) and the weighted average profile (dark blue) with $2 \sigma$ deviation (light blue). All the points shown in the left are projected onto the profile as red dots. The red line is the best-fit model with a slip rate of $8.0 \mathrm{~mm} /$ year and $14.5 \mathrm{~km}$ locking depth; (b) Model simulation map from the best-fit model values. The fat black arrow shows the north direction; (c) Residuals between model and observation (Figure 5b) results. 
Regarding error associated with these fault parameters, the main source remaining in the mean velocity map is related to residual turbulent atmospheric perturbations and orbital error in the interferograms. Therefore, we attempted to estimate the impact of such perturbations in the fault parameters by generating 100 perturbed mean velocity maps and then using the same inversion scheme as for the non-perturbed dataset. The parameter uncertainties were determined using the standard deviation of the slip and locking depth estimate from the 100 runs, which resulted in a slip rate of $8.0 \pm 0.7 \mathrm{~mm} /$ year and $14.5 \pm 3 \mathrm{~km}$ for locking depth (Figure 10).

We also performed the parameter search for each track data and assumed no vertical displacements. The best-fit parameters for D391 are $8.2 \mathrm{~mm} /$ year of slip and a locking depth of $16 \mathrm{~km}$ (blue dots in Figure 10), whereas the best-fit parameters for A298 are a slip rate of $8.3 \mathrm{~mm}$ /year and $14.8 \mathrm{~km}$ of locking depth (green dots in Figure 10). The results from the two tracks are in good agreement with each other. Figures 8 and 9 show profiles of the LOS velocity perpendicular to the strike direction of the ATF for the descending and ascending tracks, respectively, which are consistent overall with a classic arctangent shape predicted by screw dislocation models across strike-slip faults [63]. The residual maps show that the LOS velocity of the descending track (D391) fits well with the model, whereas the ascending track (A298) has some significant misfits in the southern part. This may be caused by unwrapping errors or less coherence resulting from a smaller number of SAR images.

The joint inversion results of both tracks are slightly slower because we ignored the vertical fault motion contribution in the single track inversion, as it is small relative to horizontal motion along the fault. We note that the joint inversion results are more concentrated near the best-fit parameters than the single track inversion, which demonstrates the importance of including the vertical displacements to better constrain the ATF deformation. The uncertainty for both slip rate and locking depth was reduced using SAR data from two directions as opposed to one single direction.
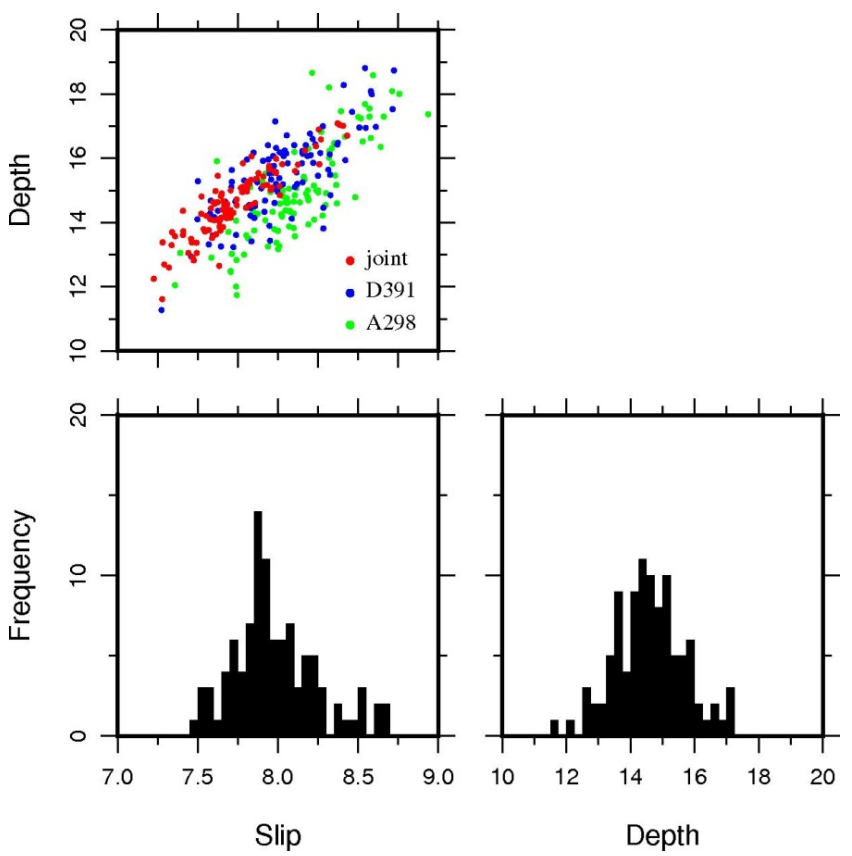

Figure 10. Results from the Monte Carlo error analysis. The red dots represent joint inversion whereas blue (D391) and green (A298) dots represent single inversions. The higher frequencies of slip rate and depth concentrate near $8.0 \mathrm{~mm} /$ year and $14.5 \mathrm{~km}$, respectively.

\section{Discussion}

After planar orbital and linear atmospheric corrections, we computed the strain rate fields using a multi-scale wavelet method. The strain fields show that deformation across the ATF is concentrated on 
the fault. England and Molnar [2] calculated crustal velocity fields and strain rates within Asia from estimates of Quaternary slip rates on faults and baseline length rates between GPS sites. They suggested that the strain rate fields determined by geodetic measurements taken on a decadal timescale are consistent with geological observations on a $10^{4}$ years timescale. Allmendinger et al. [66] derived 2-D strain and rotation rate fields from a GPS velocity field using both the nearest neighbor and distance weighted approach. Their results showed that the principal infinitesimal strain rate axes in Tibet are consistent with large, long term geological structures similar to England and Molnar [2]. Gan et al. [67] deduced the strain rate fields using 726 GPS velocities around the plateau after removing the rotational component of the entire plateau. Although the method and data set are different from England and Molnar [2], their results were generally consistent in all of the relevant areas within the plateau. Our strain fields are consistent with the first-order characteristics across the major faults from previous studies [2]. This study confirms the possibility of creating 2-D strain rate maps from InSAR data and also shows that InSAR observations can constrain velocity and strain maps with respect to GPS data.

We inverted the slip rate and fault depth using a screw dislocation model. Our preferred model implies a left-lateral displacement rate across the ATF of $8.0 \pm 0.7 \mathrm{~mm} /$ year and $14.5 \pm 3 \mathrm{~km}$ locking depth. The locking depth was not as well constrained as the other geodetic inversion results [14]. We note that the slip rate is in good agreement with GPS measurements of $9 \pm 4 \mathrm{~mm} /$ year [17] almost $1^{\circ}$ east of our study area. It is also consistent with InSAR results of $11 \pm 5 \mathrm{~mm} /$ year estimated from ERS data [16]. Similar to other geodetic measurements [15-17,68], we also identified the asymmetric deformation pattern between the two sides of the fault. The possible mechanisms to explain this interseismic velocity asymmetry maybe a variation of the elastic crustal thickness from rheological contrast on two sides of the ATF [68] or variation in fault dip angle.

Our results differ significantly from slip rates determined by geological methods (27 $\pm 7 \mathrm{~mm}$ /year; [18]) based on detailed measurements of different geomorphic terrace riser offsets using radiocarbon and cosmic ray dating. The discrepancy between these two methods could be due to the different time scales if both methods have no errors or slip rates vary with time like faults in Southern California [69]. Cowie et al. reported earlier that fault slip rates can vary in time or along strike the fault, both due to clustering or quiescence periods of the fault activity or due to long term effects $[70,71]$. Roberts et al. showed the first example of such fault slip rate variability from active faults [72]. Burchfiel et al. [73] suggested that whether the geodetically observed slip rates recorded over the last 5-10 years agree or are representative to the longer-term geologically derived slip rates is debetable. Indeed there are several examples where such a discrepancy occurs between geological and geodetic rates in several settings worldwide (e.g., Papanikolaou et al. [74]; Kenner and Simons, [75]) However, some geological authors suggest a low slip rate of the ATF that is consistent with our results. Yin et al. [76] derived an average rate of $9 \pm 2 \mathrm{~mm} /$ year since $49 \mathrm{Ma}$. This significant difference was reconciled by geologic [77] and recent geodetic [17] data, which both agree on a slip rate of $9.0 \pm 4.0 \mathrm{~mm}$ /year. As Cog will et al. [77,78] argued that the apparent discrepancy in slip rate along this fault might result more from systematic biases in geomorphic reconstructions rather than from true secular variation in slip rate.

Our consistent low slip rates along the fault are in consistent with the historical seismicity in this region. Only two great historical earthquakes have occurred along the ATF, both in 1924 west of $85^{\circ} \mathrm{E}[79,80]$. In fact, contemporary instrumental recordings also show a low level of seismicity along the ATF. Paleoseismo logical studies suggest recurrence intervals of major earthquakes in the range of $700 \pm 400$ and $1100 \pm 300$ years for offsets of 4 and $7 \mathrm{~m}$, respectively, consistent with a slip rate of $\sim 10 \mathrm{~mm} /$ year $[79,81,82]$.

Elliott et al. [16] measured the interseismic slip rate of the ATF using a stacking method with one single descending track of ERS data (1993-2000); their slip rate estimate was $11 \pm 5 \mathrm{~mm} /$ year with significant uncertainty. Here, we used the InSAR TS + AEM method with 7 years (2003-2010) of ENVISAT ASAR data and both ascending and descending tracks; our slip rate estimate was 
$8.0 \pm 0.7 \mathrm{~mm} /$ year. Our results are in agreement with results of Elliott et al. from ERS data [16] and GPS measurements ( $9 \pm 4 \mathrm{~mm}$ /year; [17]). We used the same track ENVISAT ASAR data as [16] with an additional two years of descending track data and five years of ascending track data. The difference in slip rates between our study and Elliott et al. [16] is probably a result of time-varying slip rate or stacking method assumptions that the atmospheric effect was normally distributed. However, because the topographic variation across the ATF is large, maybe it is not appropriate to assume normal distribution atmospheric errors. We had to remove any topography-correlated atmospheric errors. This study again demonstrates the importance of atmospheric and orbital corrections in InSAR time series processing. We determined our slip rate from 216 interferograms, while they used only 66 interferograms, which possibly cannot constrain the InSAR slip rate as well. Additionally, because we used ascending and descending track data, we were able to calculate the velocity parallel to the ATF as well as vertical velocity from two observing geometries and thus remove the projection of vertical deformation velocity from the LOS velocity. Elliott et al. [16] simply ignored the vertical velocity whose contributions are subtracted from the InSAR observations in our study, so their result was a little higher than ours. It is likely our calculated velocity is closer to the real velocity. We were also able to reduce the range of uncertainty for both slip rate and locking depth using two look directions of data because we used both descending and ascending track data, in comparison to the results of [16] that are based on descending track data only. This improvement demonstrates the importance of using SAR data from two look directions for interseismic studies.

It is worth noting that we simplify the model by disregarding deformation produced by the other possible surrounding secondary faults in the study area. The real tectonic setting is definitely more complex than the simple model we have used in this study. The reasons we used this simple model are that reliable SAR data near the fault were not available, which may be insufficient for a distributed slip inversion in this case; and the fault-normal and vertical deformations across the ATF are relative less with respect the strike slip $[1,2,14,15]$. Our results may include contributions of surrounding secondary faults or other mechanisms like the shrinkage or expansion of clay minerals, or even excessive water pumping or significant seasonal variations of the water table. In addition, our SAR data covered only seven years, the low temporal resolution results prevent us from extracting the varying history of fault slip rate and locking depth. Our SAR data covered only a segment of the whole ATF, we assume that our results from SAR data can represent the first-order deformation characteristics of the ATF. The detailed deformation needs further geodetic or geological study.

In Figure 7a, we have shown the vertical component of the interpolated LOS velocity obtained from two tracks of SAR data. If we assumed that the Tarim basin is static, then the south part across the ATF is uplifting with respect to the Tarim basin with nearly $3 \mathrm{~mm} /$ year velocity in agreements with Bendickand coworkers' [14] and England and Molnar's [1] results. England and Molnar [1] estimated a shortening rate of $6 \pm 4 \mathrm{~mm} /$ year across the central section of the ATF. Bendick et al. [14] reported a contraction rate of $3 \pm 1 \mathrm{~mm} /$ year across the same section. Chen et al. [83] estimated $5 \pm 2 \mathrm{~mm} /$ year across the east section at $\sim 95^{\circ}$ E. Shen et al. [15] estimate $0 \pm 2 \mathrm{~mm} /$ year convergence across the central Altyn Tagh system, which indicates strongly that north-south shortening across the ATF is negligible. Also, geologic mapping along the NATF by Cog will et al. [84] suggested that it is mostly a left slip fault with only minor compression.

Previous geodetic results based on GPS $[14,17,79]$ and InSAR $[16,68]$ data suggested a slip rate of $10 \mathrm{~mm}$ /year at different points across the ATF. Our interseismic strain accumulation profiles across the ATF are in good agreement with these previous GPS measurements and InSAR results. The slip rates and locking depth for the ATF estimated from both GPS and InSAR studies and from geological studies $[77,78]$ are also consistent with our results. This consistency indicates that the ATF played only a secondary role in the northeastward extrusion of material in the Tibetan Plateau [79], with most of the extrusion occurring in the interior of the plateau. Therefore, our results are close to the continuum models of Asian deformation requiring low fault slip rates [2,85]. 


\section{Conclusions}

Using a multi-scale wavelet method, we calculated the strain rate fields of the ATF region and determined that the strain was mainly localized along the fault, which is generally consistent with previous studies. We also show that high-resolution 2-D strain rate fields can be determined from InSAR data alone, especially in regions with spatially sparse GPS data. Based on the orbital ramp and atmospheric effect correction, we inverted the slip rate and locking depth using a screw dislocation model with ascending and descending track ENVISAT data. We performed the inversions for single track data and jointly. Our joint inversion result indicates that the ATF has a slip rate of $8.0 \pm 0.7 \mathrm{~mm} /$ year and locking depth of $14.5 \pm 3 \mathrm{~km}$. The joint inversion slip rate is a little slower than the single track inversion because of vertical deformation in the inversion. Our results are more accurate than those of Elliott et al. [16] owing to a greater number of observations in our study and the fact that we accounted for the vertical deformation in the inversion process. This study shows the importance of using both descending and ascending data in interseismic InSAR studies. As a result of the more frequent data acquisition from satellite missions, such as Sentinel-1A, ALOS-2 and the upcoming Sentinel-1B, similar studies will become increasingly common. The relative low slip rate indicates that the ATF does not transfer a significant part of the convergence between India and Asia into the northeastward extrusion of the Tibetan Plateau [76], and the deformation pattern is close to the continuum deformation models [2].

Acknowledgments: This work is co-supported by the National Natural Science Foundation of China (key program) under grants No.41431069, the National Key Basic Research Development Program (973 program) under grants No. 2013CB733304 and 2013CB733303, the China National Special Fund for Earthquake Scientific Research in Public Interest under grants No.201308009, the National Natural Science Foundation of China under grants No. 41204010 and 41404007and the Special Project of Basic Work of Science and Technology under grants No. 2015FY210400). The Envis at SAR data are provided by ESA through C1F project (ID: 29558).

Author Contributions: Caijun Xu led the research work, proposed the crucial suggestions and structure of this manuscript. Sen Zhu and Yangmao Wen designed the research, and organized the contents of the manuscript. Sen Zhu processed data and wrote the first draft of the manuscript. CaijunXu, Yangmao Wen and Yang Liu reviewed and edited the manuscript.

Conflicts of Interest: The authors declare no conflict of interest.

\section{References}

1. England, P.; Molnar, P. Active deformation of Asia: From kinematics to dynamics. Science 1997, 278, 647-650. [CrossRef]

2. England, P.; Molnar, P. Late Quaternary to decadal velocity fields in Asia. J. Geophys. Res. 2005, 110, B12401. [CrossRef]

3. Meade, J. Present-day kinematics at the India-Asia collision zone. Geology 2007, 35, 81-84. [CrossRef]

4. Thatcher, W. Microplate model for the present-day deformation of Tibet. J. Geophys. Res. 2007, 112, B01401. [CrossRef]

5. Zhang, L.; Ye, G.; Jin, S.; Wei, W.; Unsworth, M.; Jones, A.; Jing, J.; Dong, H.; Xie, C.; Le Pape, F.; et al. Lithospheric electrical structure across the Eastern Segment of the Altyn Tagh Fault on the Northern Margin of the Tibetan Plateau. Acta Geol. Sin. 2015, 89, 90-104.

6. Molnar, P.; Tapponnier, P. Cenozoic tectonics of Asia: Effects of a continental collision. Science 1975, 189, 419-426. [CrossRef] [PubMed]

7. Avouac, J.-P.; Tapponnier, P. Kinematic model of active deformation in central Asia. Geophys. Res. Lett. 1993, 20, 895-898. [CrossRef]

8. Zhang, P.Z.; Shen, Z.K.; Wang, M.; Gan, W.; Bürgmann, R.; Molnar, P.; Wang, Q.; Niu, Z.; Sun, J.; Wu, J. Continuous deformation of the Tibetan Plateau from Global Positioning System data. Geology 2004, 32, 809-812. [CrossRef]

9. Wittlinger, G.; Tapponnier, P.; Poupinet, G.; Jiang, M.; Shi, D.; Herquel, G.; Masson, F. Tomographic evidence for localized lithospheric shear along the AltynTaghFault. Science 1998, 282, 74-76. [CrossRef] [PubMed] 
10. Burchfiel, B.C.; Deng, Q.; Molnar, P.; Royden, L.; Wang, Y.; Zhang, P.; Zhang, W. Intracrustal detachment within zones of continental deformation. Geology 1989, 17, 748-752. [CrossRef]

11. Ge, W.-P.; Molnar, P.; Shen, Z.-K.; Li, Q. Present-day crustal thinning in the southern and northern Tibetan Plateau revealed by GPS measurements. Geophys. Res. Lett. 2015, 42, 5227-5235. [CrossRef]

12. Wallace, K.; Yin, G.; Bilham, R. Inescapable slow slip on the Altyn Tagh Fault. Geophys. Res. Lett. 2004, 31 , L09613. [CrossRef]

13. Houseman, G.; England, P. Crustal thickening $v$ s. lateral expulsion in the Indian-Asian continental collision. J. Geophys. Res. 1993, 98, 12233-12249. [CrossRef]

14. Bendick, R.; Bilham, P.; Freymueller, J.T.; Larson, K.M.; Yin, G. Geodetic evidence for a low slip rate in the Altyn Tagh fault system. Nature 2000, 386, 61-64.

15. Shen, Z.-K.; Wang, M.; Li, Y.; Jackson, D.D.; Yin, A.; Dong, D.; Fang, P. Crustal deformation along the Altyn Tagh fault system, western China, from GPS. J. Geophys. Res. 2001, 106, 30607-30622. [CrossRef]

16. Elliott, J.R.; Biggs, J.; Parsons, B.; Wright, T.J. InSAR slip rate determination on the Altyn Tagh Fault, northern Tibet, in the presence of topographically correlated atmospheric delays. Geophys. Res. Lett. 2008, 35, L12309. [CrossRef]

17. He, J.; Vernant, P.; Chéry, J.; Wang, W.; Lu, S.; Ku, W.; Xia, W.; Bilham, R. Nailing down the slip rate of the AltynTaghFault. Geophys. Res. Lett. 2013, 40, 5382-5386. [CrossRef]

18. Mériaux, A.-S.; Ryerson, F.J.; Tapponnier, P.; Van der Woerd, J.; Finkel, R.C.; Xu, X.; Xu, Z.; Caffee, M.W. Rapid slip along the central Altyn Tagh Fault: Morphochronologic evidence from Cherchen He and Sulamu Tagh. J. Geophys. Res. 2004, 109, B06401. [CrossRef]

19. Rosen, P.A.; Hensley, S.; Zebker, H.A.; Webb, F.H.; Fielding, E.J. Surface deformation and coherence measurements of Kilauea Volcano, Hawaii, from SIR-C radar interferometry. J. Geophys. Res. Planets 1996, 101, 23109-23125. [CrossRef]

20. Massonnet, D.; Rossi, M.; Carmona, C.; Adragna, F.; Peltzer, G.; Feigl, K.; Rabaute, T. The displacement field of the Landers earthquake mapped by radar interferometry. Nature 1993, 364, 138-142. [CrossRef]

21. Wright, T.; Parsons, B.; Fielding, E.J. Measurement of interseismic strain accumulation across the North Anatolian Fault by satellite radar interferometry. Geophys. Res. Lett. 2001, 28, 2117-2120. [CrossRef]

22. Walters, R.J.; Holley, R.J.; Parsons, B.; Wright, T.J. Interseismic strain accumulation across the North Anatolian Fault from Envisat InSAR measurements. Geophys. Res. Lett. 2011, 38, L05303. [CrossRef]

23. Xu, C.J.; Wang, H.; Jiang, G.Y. Study on crustal deformation of Wenchuan Ms8.0 earthquake using wide-swath scan SAR and MODIS. Geod. Geodyn. 2011, 2, 1-6.

24. Liu, Y.; Xu, C.J.; Wen, Y.M. InSAR measurement of surface deformation between two Da-Qaidam Mw6.3 earthquakes and joint analysis with coseismic rupture. Geod. Geodyn. 2016, 36, 110-114.

25. Papanikolaou, I.D.; Balen, R.V.; Silva, P.G.; Reicherter, K. Geomorphology of active faulting and seismic hazard assessment: New tools and future challenges. Geomorphology 2015, 237, 1-13. [CrossRef]

26. Tape, C.; Musé, P.; Simons, M.; Dong, D.; Webb, F. Multiscale estimation of GPS velocity fields. Geophys. J. Int. 2009, 179, 945-971. [CrossRef]

27. Walters, R.J.; Parsons, B.; Wright, T.J. Constraining crustal velocity fields with InSAR for Eastern Turkey: Limits to the block-like behavior of Eastern Anatolia. J. Geophys. Res. 2014, 119, 5215-5234. [CrossRef]

28. Garthwaite, M.C.; Wang, H.; Wright, T.J. Broadscale interseismic deformation and fault slip rates in the central Tibetan Plateau observed using InSAR. J. Geophys. Res. Solid Earth 2013, 118, 5071-5083. [CrossRef]

29. Ryder, I.; Parsons, B.; Wright, T.J.; Funning, G. Post-seismicmotion following the 1997 Manyi, Tibet earthquake, InSAR observations and modelling. Geophys. J. Int. 2007, 169, 1009-1027. [CrossRef]

30. Rosen, P.A.; Henley, S.; Peltzer, G.; Simons, M. Update repeat orbit interferometry package released. Eos Trans. AGU 2004, 85, 47. [CrossRef]

31. Doin, M.P.; Guillaso, S.; Jolivet, R.; Lasserre, C.; Lodge, F.; Ducret, G.; Grandin, R. Presentation of the small baseline NSBAS processing chain on a case example: The Etna deformation monitoring from 2003 to 2010 using Envisat data. In Proceedings of the European Space Agency Symposium “Fringe”, ESA SP-697. Frascati, Italy, 19-23 September 2011.

32. NSBAS. Available online: http://efidir.poleterresolide.fr/index.php/effidir-tools/nsbas (accessed on 8 March 2016).

33. Doin, M.P.; Lasserre, C.; Peltzer, G.; Cavalie, O.; Doubre, C. Corrections of stratified tropospheric delays in SAR interferometry: Validation with global atmospheric models. J. Appl. Geophys. 2009, 69, 35-50. [CrossRef] 
34. Farr, T.G.; Rosen, P.A.; Caro, E.; Crippen, R.; Duren, R.; Hensley, S.; Alsdorf, D. The shuttle radar topography mission. Rev. Geophys. 2007, 45. [CrossRef]

35. Goldstein, R.M.; Werner, C.L. Radar interferogram filtering for geophysical applications. Geophys. Res. Lett. 1998, 25, 4035-4038. [CrossRef]

36. Goldstein, R.M.; Zebker, H.A.; Werner, C.L. Satellite radar interferometry-Two-dimensional phase unwrapping. Radio Sci. 1988, 23, 713-720. [CrossRef]

37. Biggs, J.; Wright, T.J.; Lu, Z.; Parsons, B. Multi-interferogram method for measuring interseismic deformation: Denali fault, Alaska. Geophys. J. Int. 2007, 170, 1165-1179. [CrossRef]

38. Wen, Y.; Li, Z.; Xu, C.; Ryder, I.; Bürgmann, R. Postseismic motion after the 2001 MW7.8 Kokoxili earthquake in Tibet observed by InSAR time series. J. Geophys. Res. 2012, 117, B08405. [CrossRef]

39. Puysségur, B.; Michel, R.; Avouac, J.-P. Tropospheric phase delay in interferometric synthetic aperture radar estimated from meteorological model and multispectral imagery. J. Geophys. Res. 2007, 112, B05419. [CrossRef]

40. Hanssen, R. Radar Interferometry: Data Interpretation and Error Analysis; Kluwer Academic Publishers: Dordrecht, The Netherlands, 2001.

41. Cavalié, O.; Doin, M.-P.; Lasserre, C.; Briole, P. Ground motion measurement in the Lake Mead area, Nevada, by differential synthetic aperture radar interferometry time series analysis: Probing the lithosphere rheological structure. J. Geophys. Res. 2007, 112, B03403. [CrossRef]

42. Wicks, C.W.; Dzurisin, D.; Ingebritsen, S.; Thatcher, W.; Lu, Z.; Iverson, J. Magmatic activity beneath the quiescent three sisters volcanic center, central Oregon Cascade Range, USA. Geophys. Res. Lett. 2002, 29. [CrossRef]

43. Delacourt, C.; Briole, P.; Achache, J.A. Tropospheric corrections of SAR interferograms with strong topography: Application to Etna. Geophys. Res. Lett. 1998, 25, 2849-2852. [CrossRef]

44. Williams, S.; Bock, Y.; Fang, P. Integrated satellite interferometry: Tropospheric noise, GPS estimates and implications for interferometric synthetic aperture radar products. J. Geophys. Res. 1998, 103, 27051-27067. [CrossRef]

45. Li, Z.; Fielding, E.J.; Cross, P.; Muller, J.-P. Interferometric synthetic aperture radar atmospheric correction: GPS topography-dependent turbulence model. J. Geophys. Res. 2006, 111, B02404. [CrossRef]

46. Onn, F.; Zebker, H.A. Correction for interferometric synthetic aperture radar atmospheric phase artifacts using time series of zenith wet delay observations from a GPS network. J. Geophys. Res. 2006, 111, B09102. [CrossRef]

47. Li, Z.; Fielding, E.J.; Cross, P.; Muller, J.-P. Interferometric synthetic aperture radar atmospheric correction: medium-resolution imaging spectrometer and advanced synthetic aperture radar integration. Geophys. Res. Lett. 2006, 33, L06816. [CrossRef]

48. Li, Z.W.; Xu, W.B.; Feng, G.C.; Hu, J.; Wang, C.C.; Ding, X.L.; Zhu, J.J. Correcting atmospheric effects on InSAR with MERIS water vapour data and elevation-dependent interpolation model. Geophys. J. Int. 2012, 189, 898-910. [CrossRef]

49. Wadge, G.; Dodson, A.; Waugh, S.; Veneboer, T.; Puglisi, G.; Mattia, M.; Baker, D.; Edwards, S.C.; Edwards, S.J.; Clarke, P.J.; et al. Atmospheric models, GPS and InSAR measurements of the tropospheric water vapour field over Mount Etna. Geophys. Res. Lett. 2002, 29, 1905. [CrossRef]

50. Foster, J.; Brooks, B.; Cherubini, T.; Shacat, C.; Businger, S.; Werner, C.L. Mitigating atmospheric noise for InSAR using a high resolution weather model. Geophys. Res. Lett. 2006, 33, L16304. [CrossRef]

51. Foster, J.; Kealy, J.; Cherubini, T.; Businger, S.; Lu, Z.; Murphy, M. The utility of atmospheric analyses for the mitigation of artifacts in InSAR. J. Geophys. Res. 2013, 118, 748-758. [CrossRef]

52. Li, Z.; Fielding, E.J.; Cross, P.; Preusker, R. Advanced InSAR atmospheric correction: MERIS/MODIS combination and stacked water vapour models. Int. J. Remote Sens. 2009, 30, 3343-3363. [CrossRef]

53. Bekaert, D.; Hooper, A.; Wright, T. A spatially variable power law tropospheric correction technique for InSAR data. J. Geophys. Res. 2015, 120, 1345-1356. [CrossRef]

54. Bekaert, D.; Walters, R.; Wright, T.; Hooper, A.; Parker, D. Statistical comparison of InSAR tropospheric correction techniques. Remote Sens. Environ. 2015, 170, 40-47. [CrossRef]

55. Dee, D.P.; Uppala, S.; Simmons, A.; Berrisford, P.; Poli, P.; Kobayashi, S.; Andrae, U.M.; Balmaseda, A.; Balsamo, G.; Bauer, P.; et al. The ERA-Interim reanalysis: Configuration and performance of the data assimilation system. Q. J. R. Meteorol. Soc. 2011, 137, 553-597. [CrossRef] 
56. Walters, R.J.; Elliott, J.R.; Li, Z.; Parsons, B. Rapid strain accumulation on the Ashkabad fault (Turkmenistan) from atmosphere-corrected InSAR. J. Geophys. Res. 2013, 118, 1-17. [CrossRef]

57. Zebker, H.; Rosen, P.; Goldstein, R.M. On the derivation of coseismic displacement fields using differential radar interferometry: The Landers earthquake. J. Geophys. Res. 1994, 99, 19617-19634. [CrossRef]

58. Pritchard, M.E.; Simons, M. A satellite geodetic survey of large-scale deformation of volcanic centres in the central Andes. Nature 2002, 418, 167-171. [CrossRef] [PubMed]

59. Berardino, P.; Fornaro, G.; Lanari, R.; Sansosti, E. A new algorithm for surface deformation monitoring based on small baseline differential SAR interferograms. IEEE Trans. Geosci. Remote Sens. 2002, 40, 2375-2383. [CrossRef]

60. Mora, O.; Mallorqui, J.J.; Broquetas, A. Linear and nonlinear terrain deformation maps Fromareduced set of interferometric SAR images. IEEE Trans. Geosci. Remote Sens. 2003, 41, 2243-2253. [CrossRef]

61. Lundgren, P.; Hetland, E.A.; Liu, Z.; Fielding, E.J. Southern San Andreas-San Jacinto fault system slip rates estimated from earthquake cycle models constrained by GPS and interferometric synthetic aperture radar observations. J. Geophys. Res. 2009, 114. [CrossRef]

62. Hammond, W.C.; Blewitt, G.; Li, Z.; Plag, H.P.; Kreemer, C. Contemporary uplift of the Sierra Nevada, western United States, from GPS and InSAR measurements. Geology 2012, 40, 667-670. [CrossRef]

63. Savage, G.D.; Burford, R.O. Geodetic determination of relative plate motion in central California. J. Geophys. Res. 1973, 5, 832-845. [CrossRef]

64. Shirzaei, M.; Walter, T.R. Randomly iterated search and statistical competency as powerful inversion tools for deformation source modeling: Application to volcano interferometric synthetic aperture radar data. J. Geophys. Res. 2009, 114, B10401. [CrossRef]

65. He, P.; Wen, Y.; Xu, C.; Liu, Y.; Fok, H.S. New evidence for active tectonics at the boundary of the Kashi depression, China, from time series InSARobservations. Tectonophysics 2015, 653, 140-148. [CrossRef]

66. Allmendinger, R.W.; Reilinger, R.; Loveless, J. Strain and rotation rate from GPS in Tibet, Anatolia, and the Altiplano. Tectonics 2007, 26, TC3013. [CrossRef]

67. Gan, W.J.; Zhang, P.Z.; Shen, Z.K.; Niu, Z.J.; Wang, M.; Wan, Y.G.; Zhou, D.M.; Cheng, J. Present-day crustal motion within the Tibetan Plateau inferredfrom GPS measurements. J. Geophys. Res. 2007, 112, B08416. [CrossRef]

68. Jolivet, R.; Cattin, R.; Chamot-Rooke, N.; Lasserre, C.; Peltzer, G. Thin-plate modeling of interseismic deformation and asymmetry across the Altyn Tagh Fault zone. Geophys. Res. Lett. 2008, 35, L02309. [CrossRef]

69. Dolan, J.F.; Bowman, D.D.; Briole, C.G. Long-range and long term fault interactions in southern California. Geology 2007, 35, 855-858. [CrossRef]

70. Cowie, P.A.; Gupta, S.; Dawers, N.H. Implications of fault array evolution for synriftdepocentre development: Insights from a numerical fault growth model. Basin Res. 2000, 12, 241-261. [CrossRef]

71. Cowie, P.A. A healing-reloading feedback control on the growth rate of seismogenic faults. J. Struct. Geol. 1998, 20, 1075-1087. [CrossRef]

72. Roberts, G.P.; Michetti, A.M.; Cowie, P.; Morewood, N.C.; Papanikolaou, I. Fault slip-rate variations during crustal-scale strain localisation, Central Italy. Geophys. Res. Lett. 2002, 29, 91-94. [CrossRef]

73. Burchfiel, B.C.; Wang, E. Northwest-trending, Middle Cenozoic, left-lateral faults in southern Yunnan, China, and their tectonic significance. J. Struct. Geol. 2003, 25, 781-792. [CrossRef]

74. Papanikolaou, I.D.; Roberts, G.P.; Michetti, A.M. Fault scarps and deformation rates in Lazio-Abruzzo, Central Italy: Comparison between geological fault slip-rate and GPS data. Tectonophysics 2005, 408, 147-176. [CrossRef]

75. Kenner, S.J.; Simons, M. Temporal clustering of major earthquakes along individual faults due to post-seismic reloading. Geophys. J. Int. 2005, 160, 179-194. [CrossRef]

76. Yin, A.; Rumelhart, P.E.; Butler, R.; Cowgill, E.; Harrison, T.M.; Foster, D.A.; Ingersoll, R.V.; Zhang, Q.; Zhou, X.Q.; Wang, X.F.; et al. Tectonic history of the Altyn Tagh Fault system in northern Tibet inferred from Cenozoic sedimentation. Geol. Soc. Am. Bull. 2002, 114, 1257-1295. [CrossRef]

77. Cowgill, E. Impact of riser reconstructions on estimation of secular variation in rates of strike slip faulting: Revisiting the Cherchen River site along the Altyn Tagh Fault, NW China. Earth Planet. Sci. Lett. 2007, 254, 239-255. [CrossRef] 
78. Cowgill, E.; Gold, R.D.; Chen, X.; Wang, X.-F.; Arrowsmith, J.R.; Southon, J.R. Low quaternary slip rate reconciles geodetic and geologic rates along the Altyn Tagh Fault, northwestern Tibet. Geology 2009, 37, 647-650. [CrossRef]

79. Zhang, P.Z.; Molnar, P.; Xu, X. Late Quaternary and present-day rates of slip along the Altyn Tagh Fault, northern margin of the Tibetan Plateau. Tectonics 2007, 26, TC5010. [CrossRef]

80. Gu, G.; Lin, T.; Shi, Z. Catalogue of Chinese Earthquakes (1831 BC-1969 AD); Science Press: Beijing, China, 1989; pp. 1373-1388.

81. Washburn, Z.; Arrowsmith, J.R.; Forman, S.L.; Cowgill, E.; Wang, X.-F.; Zhang, Y.-Q.; Chen, Z.-L. Late Holocene earthquake history of the central Altyn Tagh Fault, China. Geology 2001, 29, 1051-1054. [CrossRef]

82. Washburn, Z.; Arrowsmith, J.R.; Dupont-Nivet, G.; Wang, X.-F.; Zhang, Y.-Q.; Chen, Z.-L. Paleoseismology of the Xorxol segment of the central Altyn Tagh Fault, Xinjiang, China. Ann. Geophys. 2001, 46, 1015-1034.

83. Chen, Z.; Burchfiel, B.C.; Liu, Y.; King, R.W.; Royden, L.H.; Tang, W.; Wang, E.; Zhao, J.; Zhang, X. Global Positioning system measurements from eastern Tibet and their implications for India/Eurasiaintercontinental deformation. J. Geophys. Res. 2000, 105, 215-227.

84. Cowgill, E.; Yin, A.; Wang, X.F.; Zhang, Q. Is the North Altyn Fault part of a strike-slip duplex along the Altyn Tagh fault system. Geology 2000, 28, 255-258. [CrossRef]

85. Vergnolle, M.; Calais, E.; Dong, L. Dynamics of continental deformation in Asia. J. Geophys. Res. 2007, 112, B11403. [CrossRef]

(C) 2016 by the authors; licensee MDPI, Basel, Switzerland. This article is an open access article distributed under the terms and conditions of the Creative Commons by Attribution (CC-BY) license (http:/ / creativecommons.org/licenses/by/4.0/). 